- Moh Zaki Arrobi

Universitas Gadjah Mada

\title{
Being a Young British Muslim in the Age of the 'War on Terror': A Critical Reflection on Interviewing a Young Muslim in Britain
}

\section{Introduction}

Since the $9 / 11$ in the USA and $7 / 7$ in the UK, followed by the global war on terror, the existence of Muslim communities in the Western countries has been widely discussed. It has been a contentious public debate where Muslim communities are scrutinised under the themes of integration, radicalisation, securitization, and now becoming part of so-called 'migrant crises' haunting across European countries. Since that, Muslim community in the West facing two challenges at the same time. First, by their Western government's Muslim community has been subsumed into 'threat' to national security, therefore, should be securitized and be placed under surveillance (Croft, 2012; Isakjee, 2012). Second, they have been experiencing a rampant Islamophobia by their fellow citizens (Bayrakli, Hafes Etc, 2015; Mustafa, 2016). Nowadays, under the climate of growing xenophobia and the rising of far-right wing, such attacks toward them has been significantly increasing.

Within the community of Muslim in the Europe, there is a considerable number of Young Muslims striving to deal with the secular-circumstance and Western culture. They are widely recognised as 'second or third generations of Muslim migrants' that emigrated from their origin countries to Western countries. In term of generational consciousness, they differ from their parents in the ways they interact and negotiate their identities with the new environment (Moazami, 2010, p. 193). Nevertheless, they are perceived still preserve their pristine culture and religion, therefore, make them difficult to integrate into society. In this context, young Muslims, as other young in the world, have been seen in two contradictory faces. On the one hand, they are regarded as 'agent of change' that bring hope and promise in building brighter future. On the other hand, they also are deemed as 'disruptive agents' which prone to criminality, radicalism, and 'security risk' in society (Bayat, 2010, p. 3). This ambivalent face of youth leads to the multiplicity of youth phenomenon, including what happen in the realm of young Muslim in the West.

Against this backdrop, the project looks to explore the process of identity construction of a Young Muslim in Britain. It advocates that the identity of a young British Muslim is underpinned by 'active citizenship' inspired by faith (Mustafa, 2016), the tendency to neo-fundamentalism (Roy, 2004), and searching for 'alternative youthfulness'(Moazami, 2010). Away from the security paradigm that places young 
Muslims in Britain as a threat to national security, it will elaborate the narratives of young Muslim in Britain through close examination of the way in which his everyday life constructing his identities.

The main research question in this project is; how a young British Muslim identity is constructed?. This main question delivered into several questions in the interview, such as family background, activism and political aspiration, elaboration on 'Muslimness' and 'Britishness', experiences of Islamophobia and racism, hobbies in spare time, and aspirations and career that he wants to pursue in the future.

\section{Interview Method used}

The interview method that adopted in this project is a face-to-face semistructured interview. As Bryman (2012, p. 471) describes, a semi-structured interview is likely used when the researcher has a focus of interests and formulate them into 'interview guide', but the interviewee has a looseness in reply the questions. In another word, this kind of interview has a certain degree of predetermined order but still ensure flexibility in the way interviewer delivers the questions (Longhurst, 2010, p. 80). The decision to use this method based on three main reasons. First, by conducting a face-to-face model, the interviewer could relatively build rapport directly and acquire both verbal and non-verbal language with the interviewee. It is recognised that one of the benefits of using a face-to-face interview is the broader opportunity to grasp emotional, non-verbal, and body language of the interviewee (Opdenaker, 2006; Wyse, 2014)

Second, through a semi-structured question the interviewer is able in generating a broader opportunity in digging deep and rich data and detailed information in specific issue from the interviewee (Bryman, 2012, p. 472). In addition, the semi-structured interview can facilitate rich description and detailed accounts of the interviewees' experiences and perspectives on a certain phenomenon (Baumbusch, 2010, p. 255). For instance, utilising a semi-structured interview is beneficial to such a complex and particular topics in this project such as the experiences of Islamophobia and the feeling between 'insider' and 'outsider'. Third, in term of technicality, it is easier to meet and to arrange an interview meeting with the interviewee because he is always available on campus on weekdays.

\section{Ethical and Methodological Implications}

Despite bringing some benefits, utilising such a method leads to certain ethical and methodological implications. Here ethic is defined as more than 'a set of procedure' before conducting fieldwork, rather it is a continuous process alongside the research process from gaining data access to publications (Wellington, 2000; Lewis, 2004). Meanwhile, methodological is defined as the ways in which knowledge is produced through certain methods within research process and closely related to ontological and epistemological thinking (Clough and Nutbrown, 2012, p. 37). Within the framework, three main issues emerge in this project at least; the 
importance of safeguarding confidentiality and well-being of the interviewee, the changing positionality of the researcher, and the trap of essentialism and orientalism in researching Islam.

First, we have to recognise that the issue of confidentiality and wellbeing in researching Muslim community is pivotal. Given the political climate of suspicion after $9 / 11$ and $7 / 7$, undoubtedly Muslim communities are 'the suspected community' especially those who live in the West (Bolognani, 2007; Ryan, Kofman and Aaron, 2011). They are a targeted group of government projects for securitization and surveillance. Therefore, safeguarding their privacy and their wellbeing are the most important issue. In this project, the researcher guarantees the confidentiality and anonymity of the interviewee through both formal consent form and informally declaring before the interview took places. It is anonymised the identity of the interviewee through change his name into the pseudo name. In addition, it did not only anonymise interviewee's name in the report but also his exact position in Islamic Society is anonymised. It based on the consideration that disclosure his position in this organisation will reveal his actual name and associate his opinion with this organisation, which is not. Meanwhile, the wellbeing of the interviewee is guaranteed in the consent form, such as the right to refuse questions, the right to terminate the interview whenever he wants, and the confidentiality of any information that he gave.

The second issue, probably the most intriguing one, emerges in this project is the positionality of the researcher. It is always uneasy to define the positionality and the relationship between the researcher and the informant. Of course, many people will automatically claim that the researcher is 'an insider' when researching Muslim due to I am also a Muslim. In doing so, they perceive 'insider position' will bring free access and rich information in conducting such research. In another word, the commonality with the interviewee is perceived will maximising benefits and minimalizing negative outcomes in this project (Zurbriggen, 2002, p. 354). Although this view is partially correct especially at the first time in gaining access and trust to the interviewee, the positionality of the researcher within this project is much more complex than 'an insider assumptions'.

It is true that I have commonalities with the interviewee not only in the religious background but also in status as a student at the University and 'minority group' in the UK. Moreover, as a Muslim, we frequently meet in Chaplaincy room to do five daily prayers. The encounters probably create the sense as being in 'one faith community'. As Bhopal (2010, p. 187) argues that identity and experience can facilitate a shared empathy and a shared understanding between the respondent and the researcher, therefore assist the researcher in developing rapport and digging personal experiences of the interviewee. For instance, it was very easy to me to contact him and to arrange the interview. Such facilities might not be obtained by researchers from different religious background.

However, the positionality of the researcher during and after the interview is much more complex than 'the easiness of insider'. Rather, the identity of the 
researcher and the respondent is not monolithic and static, but multiple and dynamic. Accordingly, assuming the researcher just 'as insider' due to his religious background is simplistic logic. The identity of the interviewer and the interviewee during the interview process is underpinned by not only religious identity, but also ethnic, gender, race, nationality, and social class (Phoenix, 1994 in Rian, Aaron, Forman, 2011:53). Moreover, in researching identity, the positionality of the researcher has multi-layered power dynamics, shifting boundaries and identities, self-censorship, multiple positioning, and fractured subjectivities (Luff, 1999; Giampapa, 2011; Ryan, Kofman and Aaron, 2011; Anna Mansson McGinty, 2013).

Only by considering the multiplicity of identity between the interviewer and the interviewee, we could critically reflect what is going on during and after the interview. In this vein, we recognise that the interviewer might not be 'fully insider' as we assumed before. In term of nationality, ethnicity, race, social class, and probably religious stream, it is obvious that the researcher and the informant having many differences. For example, the interviewer is an Indonesian citizen who was born and raised within particular religious and cultural background, while the interviewee is British citizen with Pakistani's origin and a young Londoner.

Nevertheless, we should avoid essentializing these identities as a fix and static, rather they are potentially unstable and shifting (Song and Parker 1995;244 in Ryan, Kofman and Aaron, 2011, p. 52). The contingency and shifting identities are reflected primarily throughout the interview. For example, when the interviewee told me about the experiences of being discriminated and targeted both by fellow citizens and government as the consequence of rampant Islamophobia and securitisation, I can fully understand and feel like 'one community' with him as 'minority group' within wider society. Here the researcher unconsciously becomes 'insider' and has a shared understanding with the interviewee. On the contrary, when he criticised and even blamed to other Muslims who try to 'modernise Islam' to be accepted by Western society, I did not agree at all with him based on my subjectivity and reason. Here the researcher's positionality has changed from 'insider' to 'outsider'. This shifting positionality of researcher between 'insider' and 'outsider' take places throughout the research process.

The last issue is the fundamental one that is the trap of essentialism and orientalism when researching Muslim. It has been argued that researching Muslim has a great chance to potentially fall into the trap of orientalism, reductionism, and essentialism. In considerable studies on Islam or Muslim, there are two influential views that regard Islam in Orientalism and essentialism ways. First, the camp that considering Islam as a contradictory element with the West, long time beforet $9 / 11$, Islam is viewed as 'potential threat' to the Western liberal democracy especially after the fall of communist regime in the 1990s (Huntington, 1996; Lewis, 2004; Fukuyama, 2006). Such 'clash of civilisation thesis' obviously resonates what Edward Said called on Orientalism (1979) about the misrepresentation of 'Islam' and 'East' in the West to serve colonial empire ambition. 
The second one is the tendency to view Islam as 'multifaceted religion' that lost its transcendental aspect from 'sacred text'. It emphasises on the distinction between 'great tradition' that is 'textual', 'orthodox', and 'universal' Islam in contrast to 'little tradition', which is 'localised', 'popular', and 'contextual' Islam (Assad, 1986). Such description tends to simplify religion as a mere reflection of the particular and local reality without meanings (Tibi, 2005, p. 103). The reductionism views above are embodied either in British functionalism as represented in Muslim society (1981) by Ernest Gellner or in the American tradition of cultural relativism as represented in Islam observed (1971) by Clifford Geertz (McLoughlin, 2007, pp. 282-283).

Against this backdrop, the project has tried to avoid such reductionism and essentialism in researching Muslim. On the contrary, it embraces the notion that the Muslim identity in the contemporary world is deeply influenced by global rivalry rooted in political and economic interests between Muslim's world to resist the global domination of the West (Roy, 2004; Sidel, 2007; Hadiz, 2008, 2016). In this vein, the centrality of 'global imagined Ummah' in the West seems relevant to be critically examined (Roy, 2004). In employing such frameworks into narratives, it attempts to challenge some 'common terms' and to locate Muslim as much as possible with the wider context of social, political, and cultural. For instance, it consciously refused to use the vogue term such as 'practising Muslim' and 'believing Muslim' in elucidating Muslim community in the West due to its tendency to reproduce the divisive term namely 'good Muslims' and 'bad Muslims' after 9/11. Here 'good Muslims' are the 'moderates', 'liberals', and 'secularists' versus 'bad Muslims' who are the 'radicals', 'extremist', 'Islamist' (Mamdani, 2002; Ramadan, 2010).

\section{On being 'securitised subject': a Young Muslim in the aftermath 9/11 \& 7/7}

At first, it is very important to locate the narrative of a young British Muslim in the wider context of Britain and Europe. Here, the political climate of suspicion and hatred against Muslims in the Britain and the West after $9 / 11$ and $7 / 7$ is verified by the narrative of this young Muslim man. Throughout the interview process, he told eloquently to the interviewer the narrative of Islamophobia and racism both in the conceptual and practical way. He also highlighted the importance of $9 / 11$ and 7/7 as 'a marker' in sparking hate crime against Muslim communities in Europe. Just after the moment of ' $9 / 11$ ', he said that Islam was viewed as 'something disgusting' for many Westerners.

He claims that Muslim communities in the West are facing two kinds of racism and discrimination. The first discrimination is coming from local people that view Islam and Muslims differently in term of culture, a way of life, religion, and customs. $\mathrm{He}$ said;

In essence that we are different from those people, we're dressed different the way that we the lifestyle that we choose we don't drink alcohol we don't smoke we don't have multiple partners you know we accept polygamy. These lifestyle choices which modern West does not agree with. 
The second is policies and laws of the government that discriminate Muslims and regard Muslims as 'security threat'. Here, he highly criticised 'the securitisation of Muslims' as manifest in certain policies, such as double security check in the immigration office, a policy that allows lecturers to report their students for radicalisation reason, and the uneasy condition for Muslims in running business than White people. He also experienced Islamophobia when was on the train and dressed in traditional Islamic cloth then someone degraded him in a non-verbal manner.

However, the ways in which Muslim response this situation is quite various. According to Bayoumi (2010, pp. 165166), under the discriminatory circumstances after 9/11, Muslim responses to this condition can be downplaying their identity as a Muslim, or on the contrary strengthening their identity as Muslims and developing a social network that can generate solidarity, brotherhood, and protection. In this context, the interviewee is classified into the latter category. As 'second generation' of a Pakistani family, he has socialised in a Pakistani family and neighbourhood in London that regard Islam as a source of reference and value. Not only in his family but also at the campus he has developed his peer-group primarily based on religious ties within Islamic society. Through this 'religious-social networks', he acquires a sense of belonging of community, brotherhood, solidarity, and self-actualisation.

Moreover, this 'Muslim circumstances' not only benefiting him in recognition and cultural acceptance but also encouraging him to be involved in activism and public life. $\mathrm{He}$ strives against Islamophobia, racism, and discrimination through various Muslim channels, such as Islamic Society at the University and Muslim Engagement and Developments (MEND). The latter organisation is a NonGovernment Organisation that concern to combat Islamophobia and to advocate a better policy for the Muslim community in the UK. His involvement in Islamic Society and Non-Government Organisation demonstrates his ability to engage in public life.

\section{'Religious Doctrine' or 'Western- Secular Citizenship'?}

Then, the intriguing question emerges, what is his motivation for being active in those organisations? Is he motivated by 'religious teaching' or 'a sort of secular Western citizenship?. The questions lead us to look at the meanings for such activism. In this context, the first reason that he offered for his activism is important to be heard:

My motivation to be active is, firstly, I do anything, hope my intention is correct for the sake of Allah, Allah has given me responsibility, to fulfil my duty as a Muslim, to take care Muslim community.

It is obvious that religious doctrine is very significant in shaping his activism. He stated clearly that as a Muslim, he is ordered by God to 'take care' Muslim community. In this context, he becomes 'a vanguard of Islam generation' as we have seen in the Islamic revival within young Muslim communities from the second generation in the Brooklyn the USA (Bayoumi, 2010, pp. 168-170).

Nevertheless, such a religious doctrine does not live in a vacuum. It is 
constructed by the wider context of social, cultural, and political. Accordingly, as a minority living in a circumstance where securitisation and racism are ubiquitous, 'religious doctrine' is not enough to drive activism and engagement. The local context where he born, lives, interact, and socialise is pivotal to be understood. He added:

But specifically I have a passion, in order to help Ummah within the UK especially, I believe I have this responsibility, I have grown up here, I have been through education system here, and I believe I have the skills that attribute to be able to connect Muslim community within non-Muslim community within in the UK. I think I can be the bridge because I have grown up within this society as Muslim.

He emphasised that he has grown up here, in the UK, a localised and nationalised context in which his Islamic identity is being shaped. Then, he considered that he is privileged could be 'bridge' between the Muslim community and non-Muslim community in the UK due to his background as a Muslim living in the West country.

From the narrative, it is quite convincing to argue that his activism in Muslim associations is driven neither by merely 'religious doctrine' nor by the notion of 'Western secular' citizenship. On the contrary, arguably that 'a kind of active citizenship' inspired by faith (Mustafa, 2016) engenders his engagement with the wider public life. This sort of citizenship rises within the young Muslim community, despite experiencing marginalisation and exclusion, with a very different reference and value in contrast to hegemonic model imposed either by the neoliberal regime or by nationalist demands (Isakjee, 2016, p.
1350; Mustafa, 2016, p. 454). It manifested in activism in which the notion of 'selfhelp' becomes very important while at the same time rejecting the hegemonic model of citizenship from Western values.

He criticises Britain government for being discriminatory and put Muslims under surveillance, at the same time he recognises that he was born in this land, educated here, and acquire 'skills' that beneficial for him to help Ummah also here. Furthermore, he has transformed 'this consciousness' into real activism primarily through various channels. In that sense, his narrative reflects the struggle of young Muslim to construct activism based on 'critical citizenship' (Brown \& Saeed, 2015, p.1952). Accordingly, his engagement is not only to propagate his faith but also primarily to empower his community in which he feels is being discriminated (Bayoumi, 2010; Gest, 2010; Mustafa, 2015).

Such a kind of 'active citizenship' inspired by faith has been operated within the context of secular and modern democracy of the Western country. This finding probably is quite odd amidst the dominant views that questioning 'the loyalty' of this young Muslim to their Western country (Ramadan, 2004; Isakjee, 2012; Croft, 2012) and generating moral panic on the 'threat of Islamisation of Britain' (Billaud, 2016, p. 504). As we have seen, his criticism and even his rejection towards the value of Britishness do not necessarily make him disengaged and detached from wider society. Rather, he can be active in various civic associations while at the same time criticising Western identities and values (Isakjee, 2012; Mustafa, 2016). 


\section{Islam without Culture?}

In term of political activism, he tends to be closer to Neo-fundamentalism, to call what kind of his 'Islamic political struggle' should be defined. As Oliver Roy (2004, pp. 232-238) describes, Neofundamentalism is unorganised scramble movements that manifested in various political action but has common strong tendencies, namely the calling for true tenets of Islam and deculturalisation intertwined with decontextualization as the consequence of 'deterritorialization of Islam'. Here the term of 'deterritorialization of Islam' means the spreading of Muslim across the globe without necessarily bring their pristine culture or integrate easily into the new host culture. Another feature of neofundamentalism is rejecting school of thought within Islamic tradition, therefore, easily criticising other Muslims as 'less Islam' or even 'deviant Muslims'. Such tendencies appear in his view regarding other Muslim fellows in the West. He said:

People from our own community who are segregating Islam modernising it for people to accepted. Where this is not what Islam is. Islam is what Allah reveals to us and you cannot change that. You know but there is people from own community that changing it so just to make it to people to accept.

This statement implies two implications. First, he criticises other Muslim's responses toward Western culture and perceives that as 'not what Islam is'. Likewise, throughout the interview process, he frequently uses the term of 'what really Islam is' to refer what he believes as 'true Islam' in singular and monolithic ways. Second, he contends that the notion of 'modernising Islam' is unacceptable for Muslims. In contrast, Islam is inherently fixed and cannot be influenced by any circumstances. Here the dimension of deculturalisation and decontextualization of Islam from neofundamentalism seems obvious. Therefore, the call for true tenets of Islam is the only one solution to fixing all of the problems that Muslims are facing now.

\section{A Quest for 'Alternative Youthfulness.'}

Besides his identity as Muslim, we should recognise that he is also a young man. Then, what mean to be a young Muslim man in the Western countries post9/11 and 7/7? Is he similar to another young man in the West? Or his identity as Muslim makes him 'exceptional'? In answer these questions, it is very fruitful to look at his view on what he is doing in his 'spare time'.

You know if I am busy with Islamic society something I want to busy I am with...studying something I want to study. I work I want to make money..you know everything I do. Because a lot of people these days in your spare time that means everything you are doing is you don't want to do that in your spare time you want to do. Everything I want to, away from these responsibilities as I say, I like to read books, I like to play games X-Box play station, I read poetry, I would like to play football.

He did not directly answer when he was asked about hobbies in spare time; rather he challenged the notion of 'spare time' itself by arguing 'his definition' about spare time. He criticised people who regard 'spare time' as 'escape' from the routine activity that they do not actually want to do. In contrast, for him, all of his activities are all things that he wants to do. Although he 
mentioned certain hobbies in 'his spare time' such as playing games and football, it is obvious that he prioritises 'his responsibilities' as a Muslim as well as a student over 'his hobbies'.

His view on spare time is radically different from others young man in defining their 'youthfulness'. Here the term of 'youthfulness' is defined as a social category that signifies the common denominators of youth, namely idealism, individualism, joy, spontaneity, fun, and adventurous (Bayat, 2010, pp. 26-29). However, the meaning of 'youthfulness' for him challenges the dominant version. For instance, 'youthfulness' does not mean individualism, having pre-marital sex, unlimited freedom, or even a kind of pleasure in spare time. He engenders 'youthfulness' as Muslim piety who takes responsibilities and obligations over the joy, fun, and freedom. As Moazami (2010, p. 190) argues that young Muslims in the West are searching for 'a pious youthfulness' to overcome certain youthful temptations within non-Muslim secular context. His story resonates this quest for 'pious youthfulness' within Britain's society context.

\section{Conclusion}

In short, the narrative above has attempted to present a critical reflection both at the methodological level and at the empirical level from an interview with a young British Muslim in the aftermath of 7/7 and 9/11. At the methodological level, it emerges the issue of changing and dynamic positionality between the researcher and the informant, the importance of safeguarding confidentiality and well-being of the interviewee, and the trap of essentialism in researching identity. Meanwhile, at the empirical level, it advocates that the identity construction of a young British Muslim is constructed by the tension between 'religious doctrine' and 'secular citizenship' in generating activism, tendency to embrace neo-fundamentalism, and a quest for 'alternative youthfulness'.

$* * * * *$

\section{References}

Anna Mansson McGinty, K. S. \& C. S.-J. (2013) 'Researching within and against Islamophobia: a collaboration project with Muslim communities', Social \& Cultural Geography, Vol. 14 No, pp. 1-22. Available at: http://dx.doi.org/10.1080/14649365. 2012.733406.

Baumbusch, J. (2010) 'Semi-Structured Interviewing in Practice-Close Research', Journal for Specialist in Pediatric Nursery, Volume 13.

Bayat, L. H. and A. (2010) Being Young and Muslim New Cultural Politics in the Global South and North. Oxford: Oxford University Press.

Bayoumi, M. (2010) 'Being Young, Muslim, and American in Brooklyn', in Being Young and Muslim: New 408 Cultural Politics in the Global South and North. Oxford: Oxford University Press, pp. 161-174.

Bayrakli, E., Hafes, F. and Eds (2015) European Islamophobia Report. Washington. Available at: http://www.islamophobiaeurope.com /reports/2015/en/EIR_2015.pdf.

Bhopal, K. (2010) 'Gender, Identity and 
experience: Researching marginalised groups', Women's Studies International Forum, 33, pp. 188-195.

Billaud, J. (2016) 'Snapshots of British Islam: Exploring Self, Identity, and the Good Ethical Life in the Global Megalopolis', Journal of Contemporary Ethnography, 45(5)(503-528). Available at: doi: 10.1177/0891241615578904.

Bolognani, M. (2007) 'Islam, Ethnography and Politics: Methodological Issues in Researching amongst West Yorkshire Pakistanis in 2005', Int. J. Social Research Methodology, Vol 10 No(October 2007), pp. 279-293.

Bryman, A. (2012) Social Research Methods. Fourth Edi. Oxford: Oxford University Press.

Clough, P. and Nutbrown, C. (2012) A Student Guide to Methodology: Justifying Enquiry. 3rd Editio. London: SAGE Publisher.

Fukuyama, F. (2006) The End of History and the Last Man. London: Free Press.

Geerz, C. (1971) Islam Observed: Religious Development in Morocco and Indonesia. London: The University of Chicago Press.

Gellner, E. (1981) Muslim Society. Cambridge: Cambridge University Press.

Gest, J. (2010) Apart: Alienated and Engaged Muslims in the West. London: Hurst and Company. Giampapa, F. (2011) 'The Politics of "Being and Becoming" a Researcher: Identity, Power, and Negotiating the Field', Journal of Language, Identity \& Education, 10, pp. 132-144. Available at: http://dx.doi.org/10.1080/15348458. 2011.585304

Hadiz, V. R. (2008) 'Towards a Sociological Understanding of Islamic Radicalism in Indonesia', Journal of Contemporary Asia, 38 (4), pp. 638-47. Available at: doi:10.1080/00472330802311795.

Hadiz, V. R. (2016) Islamic Populism in Indonesia and Middle East. Cambridge: Cambridge University Press.

Huntington, S. P. (1996) The Clash of Civilizations and the Remaking of World Order, Journal of World History. New York: Penguin Books. doi: 10.2307/2654621.

Isakjee, A. (2012) Tainted

Citizen: The Securitised Identities of Young Muslim Men in Birminghamt09 The University of Birmingham.

Isakjee, A. (2016) 'Dissonant belongings: The evolving spatial identities of young Muslim men in the UK', Environment and Planning A, 48(7), pp. 1337-1353. Available at: doi: 10.1177/0308518X16641110.

Katherine E. Brown \& Tania Saeed (2015) 'Radicalization and counterradicalization at British universities: Muslim encounters and alternatives', Ethnic and Racial Studies, 38, No. 11(1952-1968). Available at: http://dx.doi.org/10.1080/01419870. 2014.911343.

Lewis, A. (2004) 'Interviewing children and young people with learning disabilities : Guidelines for researchers and multi-professional practice', British Journal of Learning Disabilities, Volume 32(4 
December 2004), pp. 191-197.

Lewis, B. (2004) The Crisis of Islam: Holy War and Unholy Terror. Michigan: Modern Library Press.

Longhurst, R. (2010) 'Semi-structured Interviews and Focus Groups', in Clifford, N. and Valentine, S. F. and G. (eds) Key Methods in Geography. Second Edi. London: SAGE Publisher.

Luff, D. (1999) 'Dialogue Across the Divides: Moments of Rapport and Power in Research with AntiFeminist Women', Sociology, 33 No 4 (November 1999), pp. 687-703.

Mamdani, M. (2002) 'Good Muslim, Bad Muslim: A Political Perspective on Culture and Terrorism', American Anthropologist, 104 No 3(September 2002), pp. 766-775. Available at: http://jan.ucc.nau.edu/sj6/mamdanig oodmuslimbadmuslim.pdf.

McLoughlin, S. (2007) 'Islam(s) in context: Orientalism and the anthropology of Muslim societies and cultures', Journal of Beliefs \& Values Studies in Religion \& Education, 28. Available at: http://0www.tandfonline.com.serlib0.essex. ac.uk/doi/full/10.1080/13617670701 712539? scroll=top\&needAccess $=$ tru e.

Moazami, S. A. (2010) 'Avoiding 'Youthfulness?: Young Muslims Negotiating Gender and Citizenship in France and Germany', in Herera, L. and Bayat, A. (eds) Being Young and Muslim: New Cultural Politics in the Global South and North. Oxford: Oxford University Press. Mustafa, A. (2015) Identity and Political $1_{0}$ Participation among Young British
Muslims: Believing and Belonging . London: Palgrave MacMillan. Mustafa, A. (2016) 'Active citizenship, dissent and civic consciousness: young Muslims are redefining citizenship on their own terms', Identities Global Studies in Culture and Power, Vol. 23 No, pp. 454469. Available at: http://dx.doi.org/10.1080/1070289X. 2015.1024127\%0A@ 2015.

Ramadan, T. (2004) Western Muslims and the Future of Islam. Oxford: Oxford University Press.

Raymond Opdenaker (2006) 'Advantages and Disadvantages of Four Interview Techniques in Qualitative', Forum Qualitative Social Research. Berlin: the University of Berlin, Volume 7 N. Available at: http://www.qualitativeresearch.net/index.php/fqs/article/vie wArticle/175/391.

Roy, O. (2004) Globalised Islam The Search for A New Ummah. London: Hurst and Company.

Ryan, L., Kofman, E. and Aaron, P. (2011) 'Insiders and outsiders: working with peer researchers in researching Muslim communities', International Journal of Social Research Methodology, 14 No 1(Januari 2011), pp. 49-60.

Said, E. (1979) Orientalism. New York: Vintage Publisher.

Sidel, J. (2007) The Islamist Threat in Southeast Asia: A Reassessment. Washington: Institut of Southeast Asia Studies (ISEAS).

Stuart Croft (2012) Securitizing Islam Identity and the Search for Security. Cambridge: Cambridge University 
Press.

Talal Assad (1986) 'The Idea of Anthropology of Islam'. CENTER FOR CONTEMPORARYY ARAB STUDIES Georgetown Universit y.

Tariq Ramadan (2010) 'Good Muslim, Bad Muslim', New Statesman, 12 February. Available at: http://www.newstatesman.com/religi on/2010/02/muslim-religiousmoderation.

Tibi, B. (2005) Islam Between Culture and Politics. New York: Palgrave MacMillan.

Wellington, J. (2000) Educational Research: Contemporary Issues and
Particular Approach. London:

Continuum.

Wyse, S. E. (2014) Advantages and

Disadvantages of Face-to-Face Data Collection. Available at: https://www.snapsurveys.com/blog/a dvantages-disadvantages-facetofacedata-collection/ (Accessed: 30 December 2016).

Zurbriggen, E. L. (2002) 'Researching Sensitive Topics: Stories, Struggles, and Strategies', Feminism and Psychology, 12 (2), pp. 253-255. 